\title{
Analisis Tingkat Kepuasan Pengguna Sistem Informasi Puskesmas Menggunakan Metode End User Computing Satisfaction (EUCS) di Puskesmas
}

\section{Analysis of User Satisfaction Level of Primary Care Information System Using End User Computing Satisfaction (EUCS) Method at Primary Care}

\author{
Zefan Adiputra Golo ${ }^{1}$ \\ Subinarto ${ }^{2}$ \\ Elise Garmelia ${ }^{3}$
}

\author{
123 Jurusan Rekam Medis dan Informasi Kesehatan Poltekkes Kemenkes Semarang \\ Jl. Tirto Agung, Pedalangan, Banyumanik, Semarang \\ E-mail : zefanadiputra91@gmail.com
}

\begin{abstract}
One of the evaluation of SIMPUS application is measuring the level of user satisfaction. Puskesmas Karangtengah has implemented SIMPUS since 2009, but in the process has not been going well. The study aims to determine the level of officer satisfaction in terms of five dimensions in the End-User Computing Satisfaction (EUCS) method. The research method used was an observational survey, with a cross sectional approach. The sample in the study was 30 officers who were taken by total sampling. The data were processed using the Statistical Package for Social Sciences (SPSS). The results showed that from the five aspects of EUCS, the average officer was in the satisfied category, but for the aspects of accuracy and ease of use there were still 10 officers (33.3\%) who were dissatisfied. A total of 8 respondents $(26.6 \%)$ had a high level of satisfaction with SIMPUS, 11 respondents $(36.7 \%)$ had a moderate level of satisfaction and 11 respondents $(36.7 \%)$ had a low level of satisfaction with SIMPUS. It can't be denied that the Karangtengah Puskesmas officers are not satisfied with SIMPUS, especially in terms of accuracy and ease of use. It is recommended to improve the quality of the Primary Care Management Information System, especially in terms of the accuracy of the data generated, the use of staff and additional server capacity.
\end{abstract}

Keywords: SIMPUS, End-User Computing Satisfaction, Primary care

\begin{abstract}
Abstrak
Salah satu bentuk evaluasi penerapan SIMPUS adalah dengan mengukur tingkat kepuasan pengguna. Puskesmas Karangtengah telah menerapkan SIMPUS sejak tahun 2009, namun dalam prosesnya SIMPUS di Puskesmas Karangtengah belum berjalan dengan baik. Tujuan penelitian untuk mengetahui tingkat kepuasan petugas ditinjau dari lima dimensi pada metode End-User Computing Satisfaction (EUCS). Metode penelitian yang digunakan adalah survey observasional, dengan pendekatan cross sectional. Sampel pada penelitian sebanyak 30 orang petugas yang diambil secara total sampling, Data diolah menggunakan Paket Statistik untuk Ilmu Sosial (SPSS). Hasil penelitian menunjukkan dari lima aspek EUCS rata-rata petugas berada pada kategori puas, namun untuk aspek Keakuratan (akurasi) dan Kemudahan penggunaan (kemudahan penggunaan) masih terdapat 10 petugas $(33,3 \%)$ yang merasa tidak puas. Sebanyak 8 responden $(26,6 \%)$ memiliki tingkat kepuasan yang tinggi terhadap SIMPUS, 11 responden $(36,7 \%)$ memiliki tingkat kepuasan sedang dan 11 responden $(36,7 \%)$ memiliki tingkat kepuasan yang rendah terhadap SIMPUS. Tidak dapat disangkal bahwa petugas Puskesmas Karangtengah belum puas terhadap SIMPUS, terutama pada aspek keakuratan dan kemudahan penggunaan. Disarankan untuk meningkatkan kualitas Sistem Informasi
\end{abstract}


Manajemen Puskesmas, khususnya pada aspek keakuratan data yang dihasilkan, kemudahan penggunaan bagi petugas dan penambahan kapasitas server.

Kata kunci: SIMPUS, End-User Computing Satisfaction, Puskesmas

\section{Pendahuluan}

Berdasarkan Permenkes No. 43 Tahun 2019 Tentang Pusat Kesehatan Masyarakat, setiap Puskesmas harus menyelenggarakan Sistem Informasi Manajemen Puskesmas (SIMPUS) yang dapat diselenggarakan secara elektronik ataupun non elektronik.

Sistem Informasi Manajemen Puskesmas merupakan bagian dari sistem informasi kesehatan kabupaten/kota mencakup : pencatatan dan pelaporan kegiatan Puskesmas dan jaringannya, pencatatan dan pelaporan keuangan Puskesmas dan jaringannya, survei lapangan, laporan lintas sektor terkait, dan laporan jejaring Puskesmas di Wilayah kerjanya (Kemenkes RI, 2019)

$$
\text { Sistem Informasi Manajemen }
$$

Puskesmas adalah suatu tatanan yang menyediakan informasi untuk membantu proses pengambilan keputusan dalam melaksanakan manajemen puskesmas untuk mencapai sasaran kegiatannya. Puskesmas membutuhkan keberadaan SIMPUS, dimana dengan adanya sebuah sistem informasi manajemen, maka akan meningkatkan manajemen Puskesmas secara lebih efektif dan efisien. Selain itu prosedur pemrosesan data SIMPUS berdasarkan tenologi informasi yang tepat waktu, akurat, dan lengkap untuk mendukung pelayanan kesehatan kepada masyarakat (Depkes RI, 2004).

Puskesmas Karangtengah sebagai fasilitas pelayanan kesehatan primer telah menerapkan sistem informasi manajemen puskesmas berbasis elektronik sejak tahun 2009 untuk meningkatkan mutu pelayanan bagi pasien dan membantu pencatatan dan pelaporan setiap kegiatan/program yang dilaksanakan oleh Puskesmas.
SIMPUS yang diimplementasikan di Puskesmas Karangtengah masih belum optimal. Kendala yang masih sering terjadi adalah sistem masih sering eror, keamanan data Puskesmas yang berisiko dapat diakses siapa saja karena penggunaan password yang sama dan seringkali ada data yang tidak ditemukan. Kondisi ini tentu dapat mempengaruhi kepuasan petugas di Puskesmas Karangtengah. Salah satu bentuk evaluasi untuk menilai keberhasilan penerapan SIMPUS adalah dengan mengukur tingkat kepuasan pengguna, dalam hal ini kepuasan petugas Puskesmas terhadap SIMPUS.

Metode yang dapat digunakan untuk mengukur kepuasan pengguna adalah End User Computing Satisfaction. Metode ini menurut Doll and Torkzadeh dalam Alfiansyah et al. (2020), dapat mengukur tingkat kepuasan dari pengguna suatu aplikasi sistem informasi dengan membandingkan antara harapan dan kenyataan dari sebuah sistem informasi.

Menurut Aggelidis and Chatzoglou (2012) pengukuran kepuasan pengguna dengan metode EUCS berdasarkan pada 5 (lima) dimensi utama, yaitu content (isi), accuracy (keakuratan), format (tampilan), ease of use (kemudahan penggunaan) dan timeliness (ketepatan waktu).

Tujuan penelitian ini adalah mengetahui tingkat kepuasan petugas Puskesmas terhadap SIMPUS ditinjau dari aspek content, accuracy, format, ease of use dan timeliness.

\section{Metode}

Penelitian ini merupakan penelitian survey observasional, dengan pendekatan cross sectional. Instrument penelitian yang 
digunakan adalah kuesioner yang disebar secara online pada petugas menggunakan google form. Teknik penarikan sampel menggunakan total sampling, dimana sampel pada penelitian ini adalah 30 orang petugas Puskesmas Karangtengah yang pernah mengoperasikan SIMPUS. Pengolahan data menggunakan software Statistical Package for Social Science (SPSS).

\section{Hasil dan Pembahasan}

Responden pada penelitian ini merupakan pegawai yang bertugas di Pukesmas Karangtengah pada unit pelayanan Upaya Kesehatan Perorangan (UKP), Upaya Kesehatan Masyarakat (UKM), dan Administrasi. Pegawai yang menjadi responden harus memenuhi syarat minimal telah bekerja $>1$ tahun dan pernah mengoperasikan SIMPUS secara langsung.

Adapun karakteristik responden pada penelitian ini dapat dlihat pada tabel berikut :

Tabel 1. Distribusi Karakteristik Responden

\begin{tabular}{|c|c|c|}
\hline Karakteristik & $\mathrm{f}$ & $\%$ \\
\hline \multicolumn{3}{|l|}{ Jenis Kelamin } \\
\hline Laki-Laki & 8 & 26,7 \\
\hline Perempuan & 22 & 73,3 \\
\hline \multicolumn{3}{|l|}{ Umur } \\
\hline 20-30 Tahun & 6 & 20,0 \\
\hline 31-40 Tahun & 13 & 43,3 \\
\hline 41-50 Tahun & 9 & 30,0 \\
\hline 51-60 Tahun & 2 & 6,7 \\
\hline \multicolumn{3}{|c|}{ Tingkat Pendidikan } \\
\hline SMA & 3 & 10,0 \\
\hline D3 & 13 & 43,3 \\
\hline D4/S1 & 14 & 46,7 \\
\hline \multicolumn{3}{|l|}{ Masa Kerja } \\
\hline 1-5 Tahun & 8 & 26,7 \\
\hline 6-10 Tahun & 4 & 13,3 \\
\hline 11-15 Tahun & 6 & 20,0 \\
\hline 16-20 Tahun & 9 & 30,0 \\
\hline >21 Tahun & 3 & 10,0 \\
\hline \multicolumn{3}{|l|}{ Unit Kerja } \\
\hline UKP & 16 & 53,3 \\
\hline UKM & 5 & 16,7 \\
\hline Administrasi & 9 & 30,0 \\
\hline
\end{tabular}

Berdasarkan tabel distribusi karakteristik responden di atas, dapat diketahui bahwa responden berjenis kelamin laki-laki sebanyak 8 orang $(26,7 \%)$ dan responden berjenis kelamin perempuan sebanyak 22 orang $(73,7 \%)$. Petugas yang menjadi responden paling banyak berumur 21-40 tahun (43,\%). Tingkat pendidikan responden umumnya berada pada D4/S1 sebanak 14 orang $(46,7 \%)$ dan paling rendah tingkat pendidikan SMA sebanyak 3 orang $(10,0 \%)$. Masa kerja dari petugas yang menjadi responden paling banyak berada pada masa kerja 16-20 tahun yaitu 9 orang $(30,0 \%)$ dan paling sedikit $>21$ tahun $(3 \%)$. Responden pada penelitian ini lebih banyak bertugas pada pelayanan Upaya Kesehatan Perorangan (UKP) yaitu sebanyak 16 orang (53,3\%), sebanyak 9 orang $(30,0 \%)$ bertugas di bagian administrasi dan sebanyak 5 orang $(16,7 \%)$ bertugas pada pelayanan Upaya Kesehatan Masyarakat (UKM).

Kepuasan petugas terhadap SIMPUS diukur menggunakan metode End User Computing Satisfaction, dimana kepuasan pengguna dilihat dari 5 (lima) aspek yang dapat dijadikan indikator kepuasan terhadap sistem informasi.

Adapun kepuasan petugas dilihat dari lima aspek EUCS adalah sebagai berikut :

Tabel 2. Aspek Kepuasan Pengguna SIMPUS di Puskesmas Karangtengah

\begin{tabular}{lcccc}
\hline \multirow{2}{*}{ Aspek Kepuasan } & \multicolumn{2}{c}{ Puas } & \multicolumn{2}{c}{ Tidak Puas } \\
\cline { 2 - 5 } & $\mathbf{f}$ & $\mathbf{0}$ & $\mathbf{f}$ & $\mathbf{0}$ \\
\hline Content & 22 & 73,3 & 8 & 26,7 \\
Format & 25 & 83,3 & 5 & 16,7 \\
Accuracy & 20 & 66,7 & 10 & 33,3 \\
Timeliness & 24 & 80,0 & 6 & 20,0 \\
Ease of Uses & 20 & 66,7 & 10 & 33,3 \\
\hline
\end{tabular}

Dari tabel 2 dapat diketahui bahwa kepuasan petugas terhadap SIMPUS dilihat dari kelima aspek kepuasan pengguna rata-rata berada pada kategori puas, namun untuk aspek Keakuratan 
(accuracy) dan Kemudahan penggunaan (ease of uses) masih terdapat 10 petugas $(33,3 \%)$ yang merasa tidak puas. Banyak petugas yang menyatakan tidak puas pada aspek accuracy dikarenakan seringkali SIMPUS mengalami error ketika digunakan oleh petugas, serta informasi yang dihasilkan oleh SIMPUS terkadang belum sepenuhnya akurat. Dalam hal kemudahan pengguna (ease of uses), petugas juga membutuhkan waktu yang lama untuk mempelajari sistemnya, khususnya pada petugas yang masih baru mengoperasikannya.

Secara keseluruhan hasil analisis tingkat kepuasan pengguna SIMPUS dapat dilihat pada tabel berikut :

Tabel 3. Tingkat Kepuasan Pengguna Simpus Puskesmas Karangtengah

\begin{tabular}{lcc}
\multicolumn{1}{c}{ Level EUCS } & f & \% \\
\hline Tinggi & 8 & 26,6 \\
Sedang & 11 & 36,7 \\
Rendah & 11 & 36,7 \\
\hline \multicolumn{1}{c}{ Total } & 30 & 100,0
\end{tabular}

Berdasarkan tabel diketahui sebanyak 8 responden $(26,6 \%)$ memiliki tingkat kepuasan yang tinggi terhadap SIMPUS, 11 responden $(36,7 \%)$ memiliki tingkat kepuasan sedang, dan 11 responden (36,7\%) memiliki tingkat kepuasan yang rendah terhadap SIMPUS.

Sistem informasi manajemen merupakan kumpulan komponen (hardware, software, data, procedures, people) yang berinteraksi untuk menghasilkan informasi (Kroenke, 2011). Keberhasilan sebuah sistem informasi dapat dilihat dari tiga hal, yaitu kualitas sistem, manfaat sistem dan kepuasan pengguna (Pawirosumarto, 2016).

Menurut Saghaeiannejad-Isfahani et al. (2014), kepuasan pengguna terhadap sistem informasi menunjukkan sejauh mana pengguna puas dengan pencapaian sistem dalam memenuhi kebutuhan informasinya. Alfiansyah et al. (2020) menyatakan kepuasan pengguna merupakan penentu bagi keberhasilan penerapan suatu sistem informasi di pelayanan kesehatan. Kepuasan pengguna SIMPUS juga merupakan faktor penting dalam kinerja sistem informasi (Prasetyowati and Kushartanti, 2018).

Adanya ketidakpuasan petugas Puskesmas terhadap SIMPUS menunjukkan bahwa kualitas sistem informasi perlu ditingkatkan. Asumsi peneliti ini didukung hasil penelitian Karimi et al. (2015) dan Kuo et al. (2018) bahwa untuk meningkatkan kepuasan petugas (dokter dan perawat) terhadap sistem informasi, maka perlu peningkatan kualitas sistem informasi yang meliputi keakuratan informasi, kelengkapan, kerahasiaan, mudah dipelajari dan digunakan, serta tepat waktu untuk mendukung kebutuhan informasi.

\section{Simpulan dan Saran}

Dari hasil penelitian dapat disimpulkan bahwa petugas Puskesmas Karangtengah belum sepenuhnya merasa puas terhadap aplikasi SIMPUS, terutama pada aspek keakuratan (aacuracy) dan kemudahan dalam penggunaan (ease of uses). Olehkarena itu dapat dikatakan keberadaan SIMPUS di Puskesmas Karangtengah belum berjalan dengan baik. Masih banyaknya petugas memiliki tingkat kepuasan yang sedang dan rendah terhadap SIMPUS.

Disarankan bagi pihak Puskesmas untuk meningkatkan kualitas Sistem Informasi Manajemen Puskesmas yang digunakan selama ini, khususnya pada aspek keakuratan data yang dihasilkan, kemudahan penggunaan bagi petugas dan penambahan kapasitas server SIMPUS. Selain itu perlu dilakukan pelatihan secara berkala bagi petugas dalam upaya meningkatkan pemahaman terkait SIMPUS. 


\section{Ucapan Terima Kasih}

Peneliti mengucapkan terimakasih kepada Poltekkes Kemenkes Semarang, khususnya kepada Jurusan Rekam Medis dan Informasi Kesehatan yang telah mendukung penelitian ini.

\section{Daftar Pustaka}

Aggelidis, V. P. and Chatzoglou, P. D. (2012) 'Hospital information systems: Measuring end user computing satisfaction (EUCS)', Journal of Biomedical Informatics, 45(3), pp. 566-579. doi: 10.1016/j.jbi.2012.02.009.

Alfiansyah, G. et al. (2020) 'Evaluasi Kepuasan Pengguna Electronic Health Record (EHR) Menggunakan Metode EUCS (End User Computing Satisfaction) di Unit Rekam Medis Pusat RSUPN Dr. Cipto Mangunkusumo', Journal of Health Research Forikes Voice, 11(3), pp. 258-263. Available at: http:// forikes-ejournal.com/index. $\mathrm{php} / \mathrm{SF}$.

Depkes RI (2004) 'Kepmenkes No. 128 Tahun 2004 tentang Kebijakan Dasar Pusat Kesehatan Masyarakat'. Jakarta.

Karimi, Faezeh. et al. (2015) 'Clinical Information Systems End User Satisfaction: The Expectations and Needs Congruencies Effects', Journal of Biomedical Informatics, 53(2015), pp. 342-354. doi: 10.1016/j.jbi.2014.12.008
Kemenkes RI (2019) 'Peraturan Menteri Kesehatan RI No 43 tahun 2019 tentang Puskesmas'. Jakarta.

Kroenke, David M., (2011) 'Using Managemet Information System (MIS)', third edition, New Jersey: Prentice Hall.

Kuo, Kuang-Ming. et al. (2018) 'Strategic Improvement for Quality and Satisfaction of Hospital Information Systems', Journal of Healthcare Engineering, 2018. pp. 1-14. doi: $10.1155 / 2018 / 3689618$

Pawirosumarto, Suharno. (2016) 'Pengaruh Kualitas Sistem, Kualitas Informasi, dan Kualitas Layanan terhadap Kepuasan Pengguna Sistem E-Learning', Jurnal Ilmiah Manajemen, 6(3). pp. 416-433.

Prasetyowati, Asih and Kushartanti, Roro. (2018) 'User Satisfaction Analysis of Primary Care Information Systems in Semarang City with EUCS Model', Unnes Journal of Public Health, 7(2). pp. 120-125.

Saghaeiannejad-Isfahani, Sakineh. et al. (2014) 'A Survey on the Users' Satisfaction with the Hospital Information Systems (HISs) based on DeLone and McLean's Model in the Medical-Teaching Hospitals in Isfahan City', Journal of Academy of Mdical Sciences of Bosnia and Herzegovina, 22(3). pp. 179-182. doi: 10.5455/aim.2014.22.179-182 